\title{
Publisher Correction: Sex-dependent dominance maintains migration supergene in rainbow trout
}

Devon E. Pearse (D), Nicola J. Barson (D), Torfinn Nome, Guangtu Gao, Matthew A. Campbell (D, Alicia Abadía-Cardoso, Eric C. Anderson, David E. Rundio, Thomas H. Williams, Kerry A. Naish (D), Thomas Moen, Sixin Liu, Matthew Kent, Michel Moser, David R. Minkley, Eric B. Rondeau (D), Marine S. O. Brieuc, Simen Rød Sandve (D), Michael R. Miller, Lucydalila Cedillo, Kobi Baruch, Alvaro G. Hernandez, Gil Ben-Zvi(D, Doron Shem-Tov, Omer Barad, Kirill Kuzishchin, John Carlos Garza, Steven T. Lindley, Ben F. Koop D, Gary H. Thorgaard, Yniv Palti (D) and Sigbjørn Lien (D)

Correction to: Nature Ecology \& Evolution https://doi.org/10.1038/s41559-019-1044-6, published online 25 November 2019.

This Article was originally published under subscription copyright, but should have been available on an open access basis under a Creative Commons licence (CC BY 4.0). This has now been amended.

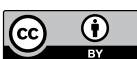

Open Access This article is licensed under a Creative Commons Attribution 4.0 International License, which permits use, sharing, adaptation, distribution and reproduction in any medium or format, as long as you give appropriate credit to the original author(s) and the source, provide a link to the Creative Commons license, and indicate if changes were made. The images or other third party material in this article are included in the article's Creative Commons license, unless indicated otherwise in a credit line to the material. If material is not included in the article's Creative Commons license and your intended use is not permitted by statutory regulation or exceeds the permitted use, you will need to obtain permission directly from the copyright holder. To view a copy of this license, visit http://creativecommons.org/licenses/ by/4.0/.

Published online: 9 December 2019

https://doi.org/10.1038/s41559-019-1076-y

(c) The Author(s) 2019 